\title{
Monitoring Of Macronutrients Uptake by Soil and Potato Plants - A Comparative Study
}

\author{
Dr. (Mrs.) Rita Bajpai \\ Assistant Professor, Dr. J. P.M. Govt. Science College, Mungeli
}

\begin{abstract}
Soil test ${ }^{1,2}$ is necessary to identify optimal concentrations of essential elements required for plant growth. The fertility of soil is affected by the presence of some essential elements as Macronutrients like N, $P \&$ $K$. This study including the status of Macronutrients in the soil and potato plans. The percentage of nitrogen $(N)$ in soil of potato plant was obtained $5.6 \%$ and $1.89 \%$ where as nitrogen percentage in plant ash was $17.45 \%$ and $16.4 \%$ respectively.

But the phosphorus and potassium are present in adequate amount in soil. As it was found that the concentration of phosphorus $(P)$ and potassium $(K)$ in part per million in soil of potato was 62ppm and $148.3 p p m$ and in potato plant ash the concentration was 64.23ppm and 103.3ppm respectively.

Keywords: Optimal concentration, essential elements, fertility, macronutrients,
\end{abstract}

\section{Introduction}

The macro and micro nutrients were effect the fertility of soil ${ }^{2}$ and growth of plants. The methods were described for determining Nitrogen, phosphorous \& Potassium in plant tissues and soil(humus), Its result indicate a correlation content with nutrients extraction and fertilizer applications. The aim of the paper is to determine the effect of macronutrient in fertility of soil and growth of potato plant.

The concentration of nutrients in plant tissues can be measured in a plant extract obtained from fresh plant material, (i.e., tissue analysis), as well as in whole dried plant material. Total plant analysis is quantitative in nature and is more reliable and useful.

Phosphorus ${ }^{1,5}$, Potassium, Nitrogen is an essential element for all plants. Plants will grow slowly with low levels of Phosphorus, Potassium and Nitrogen in the soil; however, for agricultural production purposes, the soil should provide a sufficient concentration of $\mathrm{P}$ for optimum plant growth.

While this goal is easily stated, it is difficult to determine whether or not soil P is sufficient for optimum plant production. Consequently, much effort has been dedicated to the development of soil tests that determine the concentration of plant-available $\mathrm{P}$, and whether or not that concentration is sufficient for optimum crop growth.Soil testing has been practiced in one.

Nitrate ${ }^{2,3}$ in plant tissue are readily water soluble and is extracted by water from samples that have been oven dried and finely ground. Nitrate is quantitatively reduced to nitrite. Soil test extract ants for phosphorus and potassium ${ }^{4}(\mathrm{~K})$ were designed to rapidly assess the available nutrient status of soils. They serve as the basis for making recommendations for the addition of plant nutrients needed to achieve optimum yields.

Most extract ants for P were developed to estimate the capacity of the soil to supply P to plants. They were designed to dissolve and/or desorb some fraction of the labile $\mathrm{P}$ and thus provide an index of the availability of $\mathrm{P}$ to crops over the growing season.

\section{Materials \& Methods}

As the purpose of this study was to investigate the percentage composition of some important element, essential for growth and development of plants thus The resultant weight percentage of macronutrient present in potato plant and their respective soil sample is obtained from following methods all chemical used are 'A' grade, macronutrient were analyzed by different techniques (chemicals, reagent, flame photometry).

\section{NITROGEN $5,6,9$ :}

$5 \mathrm{gm}$ of sample was taken in kjeldahl flask, added $1 \mathrm{gm}$ of $\mathrm{CuSO}_{4}$ and $5 \mathrm{ml}$ conc. $\mathrm{H}_{2} \mathrm{SO}_{4}$. Heated the mixture about 2 hour continue till the color of the mixture become more or less transparent .mixture was cooled and diluted with distilled water mixture was transfer to distillation unit . Neutralized the solution mixture with conc. $\mathrm{NaOH}$ solution added a few glass beads.

Taken $25 \mathrm{ml}$ of $0.1 \mathrm{~N}^{\mathrm{H}} \mathrm{H}_{2} \mathrm{SO}_{4}$ solution in a conical flask as a receiver. Heated the mixture, distillate was collect in the receiver, stopped heating and remove the flask. Distillate was titrate with .1N NaOHsolution, observed and total nitrogen calculated. 
PHOSPHORUS ${ }^{7,10}$ :

$1 \mathrm{gm}$ of dried powered sample was digested with $30 \mathrm{ml}$ of $10 \% \mathrm{H}_{2} \mathrm{SO}_{4}$ for half an hour on a water bath. The content filtrated and filtrate was transferred to beaker and $10 \mathrm{ml}$ of conc. $\mathrm{HNO}_{3}$ were added to it. Mixture was warmed after stirring. The precipitate of ammonium phosphomolybdate so obtained was filtered through whatman filter paper no.44 and washed with dilute potassium nitrate solution. This precipitate was then dissolved in excess of $\mathrm{N} / 10$ standard $\mathrm{NaOH}$ solution and the excess alkali was titrated with N/10 standard $\mathrm{HCl}$ using phenolphthalein as indicator. Form the titer value, phosphorus content was determined.

\section{POTASSIUM ${ }^{8}$ :}

Woodruffs method $-5 \mathrm{~g}$ of soil were taken in $100 \mathrm{ml}$ screw capped bottle and $1.5 \mathrm{ml}$ of distilled water was added to it and was kept undisturbed overnight $.35 \mathrm{ml}$ of $0.01 \mathrm{~m} \mathrm{CaCl} \mathrm{Cl}_{2}$ solution was added to it and contents were properly shaken for 1 hour and were filtered .K contents in the soil were determine using flame photometer which was calibrated with $0.01 \mathrm{~m} \mathrm{CaCl}_{2}$ solution.

Macronutrients in plant ash were analyzed by digestion followed by distillation of dry plants. N, P \& K were analyzed by kjeldahl method, Spectrophotometric method \& by flame photometer respectively

Table 1: macro nutrients of soil samples of potato plant

\begin{tabular}{|c|c|c|c|}
\hline \multirow[b]{2}{*}{ Industries } & \multicolumn{2}{|c|}{ Macro Nutrients } & \\
\hline & Nitrogen $(\%)$ & Phosphorus(ppm) & Potassium (ppm) \\
\hline S E M L & 5.8 & 62.6 & 148 \\
\hline
\end{tabular}

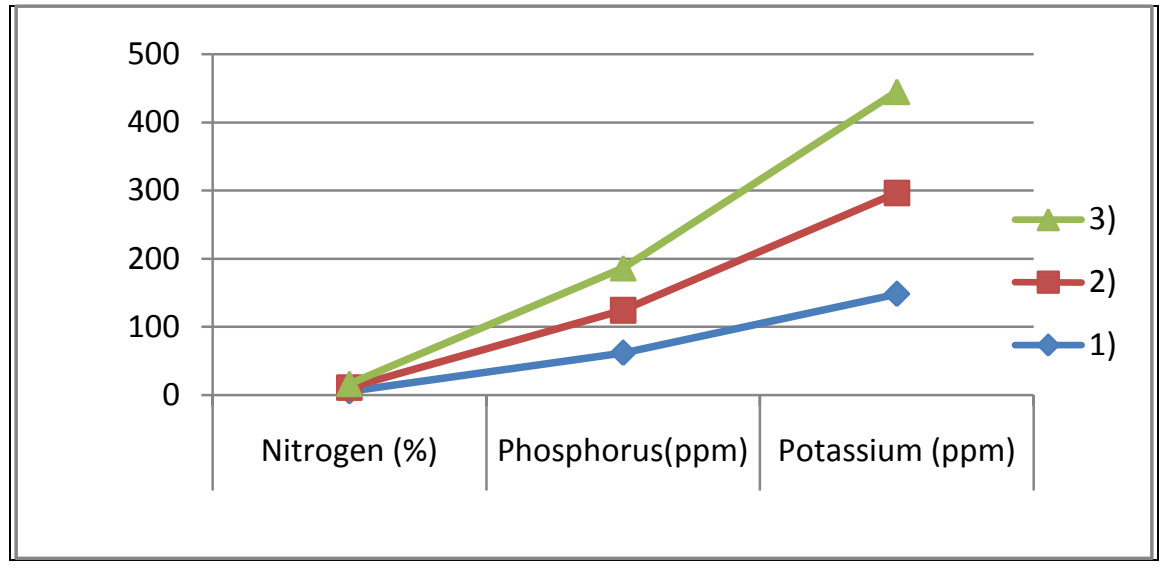

Graph-1 macro nutrients of soil samples of potato plant

Table 2: macro nutrient of samples potato plant ash

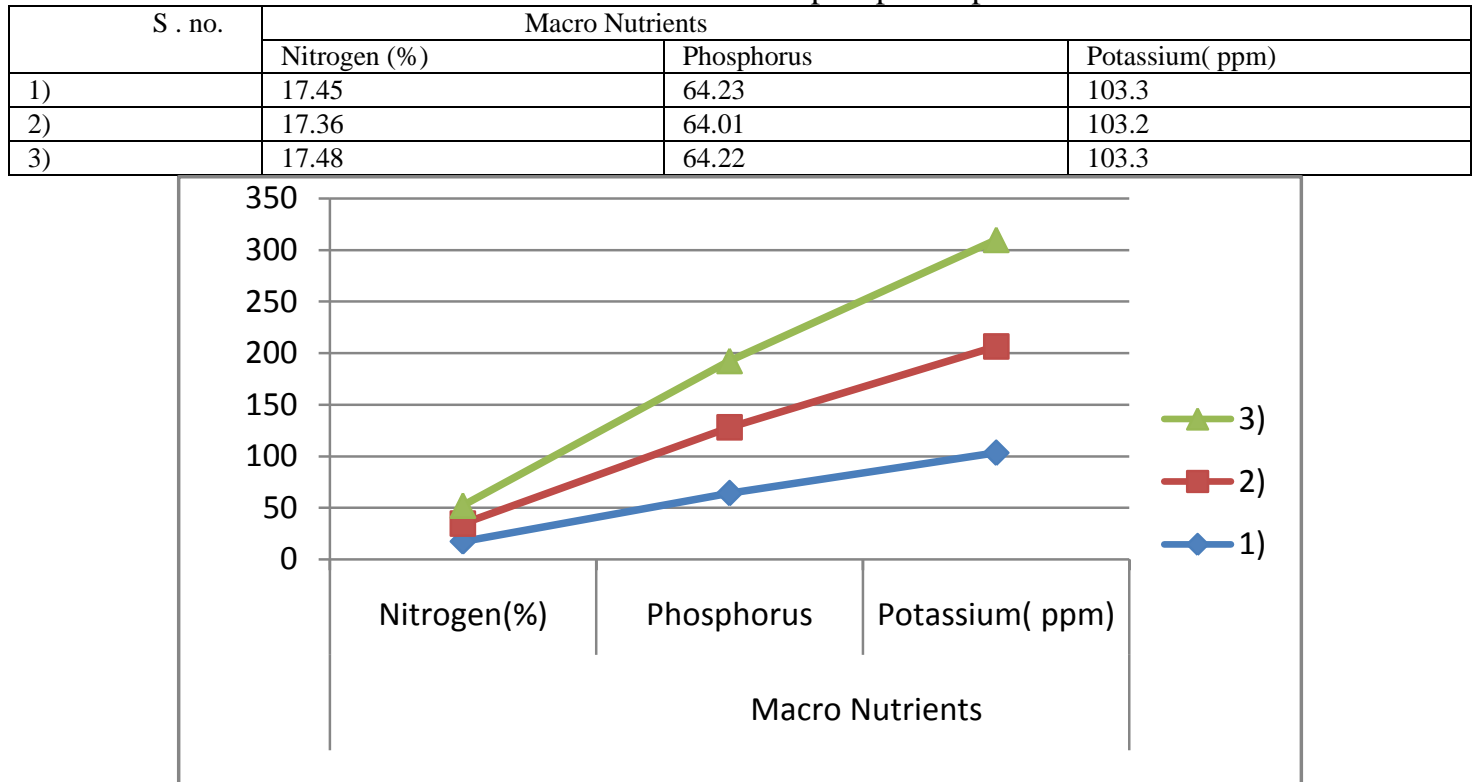

Graph-2 macro nutrients of samples of potato plant ash 


\section{Results And Disscution}

In collected soil samples of potato plants and their respective plant ash were analyzed by different method and procedure. After analyzing it was found that from macro nutrients the percentage of available nitrogen in soil sample was less than that of in their plant sample.

- The percentage of nitrogen $(\mathrm{N})$ in soil of potato plant was obtained $5.6 \%$ and where as nitrogen percentage in plant ash was $17.45 \%$.

- But the phosphorus and potassium are present in adequate amount in soil.As it was found that the concentration of phosphorus $(\mathrm{P})$ and potassium $(\mathrm{K})$ in part per million in soil of potato was $62 \mathrm{ppm}$ and $148.3 \mathrm{ppm}$ and in potato plant ash the concentration was $4.23 \mathrm{ppm}$ and $103.3 \mathrm{ppm}$ respectively.

Table-3 comparative data of macro nutrients of soil samples of potato plant \& plant ash

\begin{tabular}{|l|l|l|}
\hline \multirow{2}{*}{ Macronutrient } & \multicolumn{2}{|c|}{ POTATO PLANT } \\
\cline { 2 - 3 } & Soil sample & Plant ash sample \\
\hline $\mathrm{N}$ & 5.6 & 17.45 \\
\hline $\mathrm{P}$ & 62 & 64.23 \\
\hline $\mathrm{K}$ & 148.2 & 103.3 \\
\hline
\end{tabular}

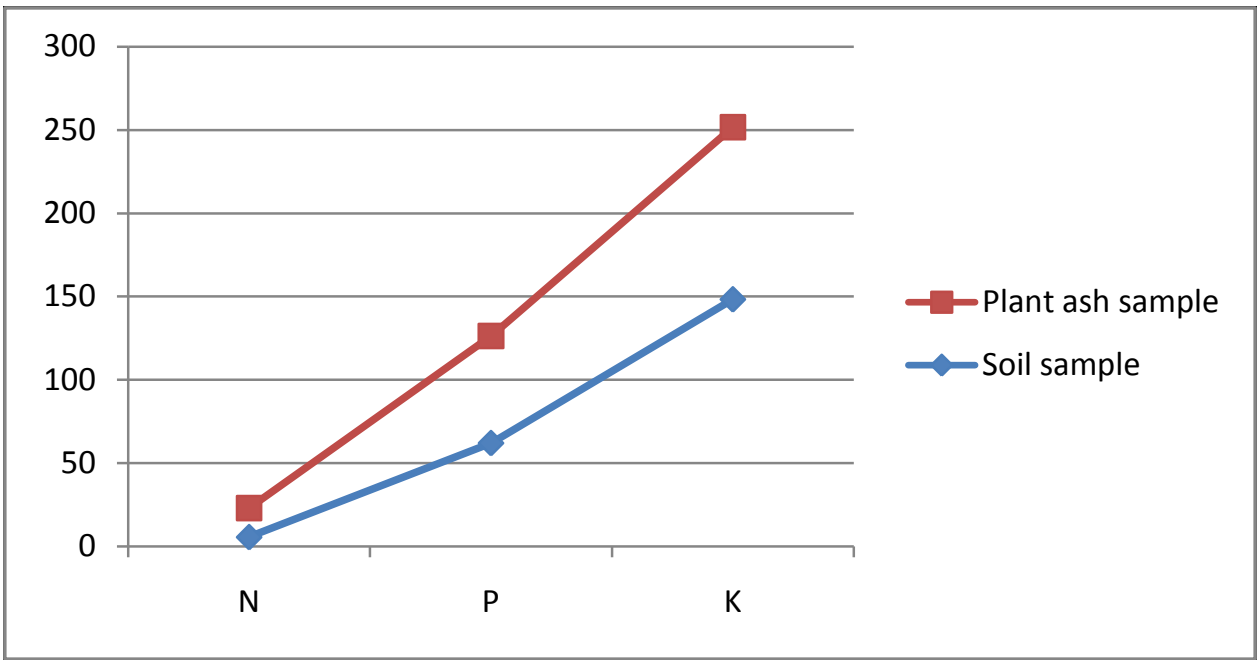

Graph-3 macro nutrients of samples of soil of potato plant \& potato plant ash

\section{Conclusion}

Considering the concept of "soil, plant nutrient index" the soil sample of their respective plant tomato and potato were found in category of moderate fertility status for potassium and phosphorus but having low fertility status for Nitrogen. Deficiency of nitrogen leads to sever disorder in crops such as narcosis. urea can be use to remediate the low fertility power of soil.

\section{References:}

[1]. SoilSamplingandAnalysis:JamesL.Walworthcals.arizona.edu/pubs/crops/az1412.pdf, Originally published: 2006

[2]. Recommended Soil Tests for Macro and Micronutrients Ann Wolf and Douglas Beegle, Last Revised 10/200

[3]. Comparison of Laboratory and Quick-test Methods for Forage Nitrate. MacKown and Weik 2004

[4]. Soil-plant transfer of trace elementsAlinaKabata-Pendias27 February2004.

[5]. The three-dimensional distribution of minerals in potato tubers: Subramanian, Philip J. White, Martin R. Broadley,GavinRamsay,Received September 15, 2010

[6]. Determination of mineral elements in plant tissue using trichloroacetic acid extraction: Glen E. Leggett and Dale T. Westermann, 1973.

[7]. Influence of Species of Vesicular-ArbuscularMycorrhizalFungi and Phosphorus Nutrition on Growth, Development, and Mineral Nutrition of Potato (Solanumtuberosum 1.) David A. J. McArthur and N. Richard Knowles, 1993.

[8]. Mehlich 3 soil test extractant: A modification of Mehlich 2extractant. Communications in Soil Science and Plant Analysis, 15:1409. Mehlich, A. 1985

[9]. Nitrogen-Inorganic Forms. In Methods of Soil Analysis: Chemical Methods. Part 3. D.L. Sparks, editor. Soil Sci. Soc. of Am., Madison WI. Mulvane, R.L. 1996

[10]. Phosphorus. In Methods of Soil Analysis: Chemical Methods. Part 3. D.L. Sparks, editor. Soil Sci. Soc. of Am., Madison WI. Kuo, S. 1996. 